\title{
Assessment of the Nutritional Status, Bone Mineralization, and Anthropometrics of Children with Thalassemia Major
}

\section{Talasemi Majörlü Çocuklarda Nutrisyonel Durumun, Kemik Mineralizasyonu ve Antropometrik Ölçümlerin Değerlendirilmesi}

\section{(D) Serap Cevher BULGURCU1, (1) Aylin CANBOLAT AYHAN2, (1) Hamdi Cihan EMEKSIZ3, (D) Fahri OVALII}

IIstanbul Medeniyet University Faculty of Medicine, Department of Pediatrics, Istanbul, Turkey

2Istanbul Medeniyet University Faculty of Medicine, Department of Pediatric Hematology-Oncology, Istanbul, Turkey

3Istanbul Medeniyet University Faculty of Medicine, Department of Pediatric Endocrinology, Istanbul, Turkey

\begin{abstract}
Objective: Children with thalassemia major (TM) are prone to growth failure and micronutrient deficiency. Thus, this study aimed to evaluate nutritional status, anthropometrics, and bone mineralization defects in patients with regular blood transfusion.

Methods: Data obtained were analyzed by evaluating laboratory tests, anthropometric measures, and bone mineral density.

Results: This study included 29 patients ( $62 \%$ male and $38 \%$ female) with a mean age of $12.26 \pm 4.74$ years, mean pre-transfusion hemoglobin of $8.64 \pm 1.01 \mathrm{~g} / \mathrm{dL}$, and mean serum ferritin of $1158.6 \pm 556.8 \mathrm{ng} /$ $\mathrm{mL}$. Vitamin D $(72.4 \%)$, selenium $(72.4 \%)$, and folate (37.9\%) deficiencies were most frequent. Hypocalcemia was observed in $17.2 \%$, hypomagnesemia in $3.5 \%$, and decreased ceruloplasmin in $10.3 \%$ of patients. Folate was higher between 2 and 6 years old ( $p=0.028$ ). Ceruloplasmin was higher between 6 and 10 years old $(p=0.018)$. Selenium was significantly higher in patients with a ferritin of $\geq 1,500$ ( $p=0.008)$. No significant ferritin-related differences were found in other micronutrients ( $p>0.05)$. Body mass index (BMI) were $<5$ percentile (p) in $31 \%$ of patient, whereas none was $>95$ p. Height in $24.5 \%$ and weight in $20.7 \%$ of patients were $<3$, whereas none with $>97$. BMI of patients aged 10-18 years was significantly higher $(p=0.001$ ). Anthropometric percentiles did not significantly differ in the mean serum ferritin and micronutrient levels. Hypoparathyroidism was observed in $13.8 \%$ and hypothyroidism in $3.5 \%$ of patients. Low bone density was detected in $14.8 \%$ ( 2 osteopenic and 2 osteoporotic) of patients. Bone mineral density did not significantly differ in the ferritin and micronutrient levels.

Conclusions: Nutritional support and deficiency prevention are important to minimize the burden of complications and increase the life expectancy and quality in patients with TM.

Keywords: Thalassemia, micronutrient, anthropometric, osteopenia, body mass index
\end{abstract}

Received: 22 July 2021 Accepted: 27 November 2021 Online First: 17 December 2021

Corresponding Author A. Canbolat Ayhan Istanbul Medeniyet University Faculty of Medicine, Department of

Pediatrics, Istanbul, Turkey canbolataylin@hotmail.com ORCID: 0000-0001-6173-2350

Presented in: The study was presented as an oral presentation in $12^{\text {th }}$ Eurasian Hematology-Oncology Congress, Istanbul, Turkey, November $10-13,2021$

Öz

Amaç: Talasemi majör (TM) tanılı çocuklar büyüme geriliğine ve mikrobesin eksikliklerine yatkındırlar. Bu çalışmada, düzenli transfüzyon uygulanan hastalarda mikro besin seviyelerini, antropometrik ölçümleri, kemik mineralizasyon defektlerini değerlendirmeyi amaçladık.

Yöntemler: Laboratuvar testlerini, antropometrik ölçümleri ve kemik mineral yoğunluğunu değerlendirerek elde edilen verileri analiz ettik.

Bulgular: Çalışmaya ortalama yaşı $12,26 \pm 4,74$ yll, ortalama transfüzyon öncesi hemoglobin $8,64 \pm 1,01 \mathrm{~g} / \mathrm{dL}$, ortalama serum ferritin $1158,6 \pm 556,8 \mathrm{ng} / \mathrm{mL}$ olan 29 hasta (\%62'si erkek, \%38'i kız) alındı. En sık vitamin D $(\% 72,4)$, selenyum $(\% 72,4)$ ve folat $(\% 37,9)$ eksikliği saptandı. Hastaların \%17,2'de hipokalsemia, \%3,5 hipomagnesemi, \%10,3 seruloplazmin düşüklüğü saptandı. Folat $2 \leq$ ile $<6$ yaş arasında, seruloplazmin $6 \leq$ ile $<10$ yaş arasında daha yüksek saptandı (sırasıyla $p=0,028, p=0,018$ ). Selenyum, ferritin $\geq 1.500$ olan hastalarda anlamlı olarak yüksekti $(p=0,008)$. Diğer mikrobesin düzeylerinde ferritin düzeyi ilişkili anlamlı farklılık

Cite as: Bulgurcu SC, Canbolat Ayhan A, Emeksiz HC, Ovali F. Assessment of the Nutritional Status, Bone Mineralization, and Anthropometrics of Children with Thalassemia Major. Medeni Med J 2021;36:325-332

${ }^{\circledR}$ Copyright 2021 by the Istanbul Medeniyet University / Medeniyet Medical Journal published by Galenos Publishing House.

Licenced by Creative Commons Attribution-NonCommercial 4.0 International (CC BY-NC 4.0) 
saptanmadı (p>0,05). Hastaların \%3l'inin vücut kitle indeksi (VKi) 5. Persentilin (p) altındaydı. VKi 95. p'nin üzerinde olan hasta saptanmadı. Hastaların \%24,5'inin boyu, \%20,7'sinin vücut ağırlığı 3. p'nin altındaydı. Boy ve vücut ağırlığı açısından 97. p'nin üzerinde olan hasta saptanmadı.

Antropometrik ölçümlerin, hastaların kan mikrobesin ve ferritin düzeyleri ile anlamlı bir ilişkisi saptanmadı. On-18 yaş arasındaki hastaların VKi anlamlı olarak daha yüksek bulundu ( $\mathrm{p}=0,001)$. Antropometrik ölçümler, ortalama ferritin ve mikrobesin düzeyleri açısından anlamlı farklılık göstermedi. Hastaların $\% 20,8$ 'de endokrinolojik bozukluklar (hipoparatiroidi \%13,8, hipotiroidi \%3,5) gözlendi. Hastaların \%14,8'inde (2 osteopenik, 2 osteoporotik) düşük kemik yoğunluğu saptandı. Kemik mineral yoğunluğunun mikrobesin ve ferritin düzeyleriyle anlamlı ilişkisi saptanmadı.

Sonuçlar: TM hastalarında nütrisyonel eksikliklerin önlenmesi ve beslenme desteğinin sağlanması kemik mineralizasyon bozuklukları ve büyüme geriliği gibi komplikasyonların gelişiminin en aza indirilmesi açısından önemlidir.

Anahtar kelimeler: Talasemi, mikrobesin, antropometrik, osteopeni, vücut kitle indeksi

\section{INTRODUCTION}

Thalassemia major (TM) is one of the chronic diseases in which nutritional deficiencies and endocrine complications are common. Increased iron overload, poor dietary intake, metabolic complications, and endocrinological disturbances are among the factors, which contribute to the nutritional status of these patients'. Nutritional deficiency is related to multiple factors but hepatic iron overload is a significant cause of deficits in $\mathrm{TM}^{2}$. Patients with thalassemia do not have a specific diet and supplementation has been demonstrated with a weak effect on the circulating nutrients ${ }^{1.2}$. Thus, this study aimed to evaluate nutritional deficiencies, endocrinological dysfunctions, anthropometric measurements, and bone mineralization defects and assess their association with serum ferritin levels and age in children with TM.

\section{MATERIALS and METHODS}

This study included children with beta TM who have visited Istanbul Medeniyet University Goztepe Training and Research Hospital Pediatric Hematology-Oncology Department for regular blood transfusion. The study protocol was approved by the University of Health Sciences Turkey, Istanbul Medeniyet University Goztepe Training and Research Hospital Clinical Research Ethics Committee (decision no: 2019/0267, date: 22.05.2019) and written informed consent was obtained from the parents. Patients with known comorbidities, such as gastrointestinal, renal, or eating disorders, were excluded. The height and body weight were measured on the same day with blood sample collection. All measurements were taken by the same person. Height and weight percentiles (p) for age and sex were compared with reference data for Turkish children ${ }^{3}$. Body mass index (BMI) was calculated by dividing the weight in kilogram by the square of height in meters. Obesity was defined as BMI of $\geq 95 p$, overweight as 85-95 p, normal weight as 5-85 p, and low weight was defined as BMI of $<5$ p. Height of $<3$ p was defined as short stature and height $>97 \mathrm{p}$ was defined as tall $^{3}$. All laboratory assessments and dual-energy X-ray absorptiometry (DXA) measurements were performed at our hospital. Laboratory evaluations included pretransfusion hemoglobin, serum ferritin, vitamins C, E, $\mathrm{D}$, and B12, folate, selenium, zinc, calcium, phosphorus, magnesium, albumin, total protein, ceruloplasmin, alkaline phosphatase, morning fasting glucose, glycated hemoglobin (HbAlc), insulin, thyroid-stimulating hormone, thyroxine, and parathyroid hormone (PTH). An average ferritin level was calculated by averaging serum ferritin values drawn in the last 6 months before the study to obtain a more accurate value. Vitamin D level of $\geq 30 \mathrm{ng} /$ $\mathrm{mL}$ was defined as normal, $<20 \mathrm{ng} / \mathrm{mL}$ was a deficiency, and $20-30 \mathrm{ng} / \mathrm{mL}$ was insufficiency ${ }^{4}$. Hyperglycemia was defined as fasting blood sugar of $\geq 100 \mathrm{mg} / \mathrm{dL}$. All patients received iron chelation and prescribed folic acid but were not questioned for treatment compliance. Bone mineral density (BMD) was performed for 26 patients who were $\geq 6$ years old and was measured by DXA (Lunar-DPXIQ, GE-Lunar corp. Madison, Wisconsin, USA). The lumbar spine (L1-L4) was scanned. Results were expressed as age and gender standardized Z-scores. BMD Z-score lower than -2 standard deviation (SD) indicated osteoporosis and between -2 and -1 SD indicated osteopenia. A Z-score higher than -1 SD indicated normal BMD. Data from the anthropometric measurements, laboratory results, and DXA were analyzed. Patients were evaluated in three agerelated groups and three ferritin-level-related groups to evaluate the effects of age and ferritin levels on these parameters.

\section{Statistical Analysis}

The statistical analyses were performed using the Statistical Package for the Social Sciences version 17.0. The variable compliance to normal distribution was examined using histogram graphics and the KolmogorovSmirnov test. Mean, standard deviation, and median values were used for descriptive analyzes. Categorical variables were compared using the Pearson chi-square 
test. The Mann-Whitney U test was used to evaluate nonparametric variables between the two groups, and the Kruskal-Wallis test was used when evaluating more than two groups. The Spearman correlation test was used to analyze the measurement data with each other. A p-value of $<0.05$ was considered statistically significant.

\section{RESULTS}

This study included 29 patients aged 2.33-18 (mean $12.26 \pm 4.74)$ years, wherein $18(62 \%)$ were male and $11(38 \%)$ were female. The mean pre-transfusion hemoglobin level was $8.64 \pm 1.01 \mathrm{~g} / \mathrm{dL}$ (range: $5.8-10.6 \mathrm{~g} / \mathrm{dL}$ ). The mean serum ferritin was $1158.6 \pm 556.8 \mathrm{ng} / \mathrm{mL}$ (range: 3632,842). No significant difference was found between sex and ferritin concentration ( $p>0.05)$. Vitamin D (72.4\%), selenium $(72.4 \%)$, and folate $(37.9 \%)$ deficiencies were most frequent. Hypocalcemia was determined in $17.2 \%$, hypomagnesemia in $3.5 \%$, and decreased ceruloplasmin in $10.3 \%$. The prevalence of micronutrient deficiencies and biochemical and endocrine disturbances are shown in Table 1. None of our patients was overweight but $20.7 \%$ (7 patients) were with low weight. Height of $>97 \mathrm{p}$ and BMI >95 p was also not observed. The anthropometric measurements of patients are shown in Table 2 . Anthropometric percentiles did not significantly differ in terms of mean serum ferritin concentration. Ferritin levels according to Anthropometrics are summarized in Table 3. Patient data were compared by dividing them into groups according to both age and serum ferritin levels. Accordingly, patients were divided into three age groups: 2-6, 6-10, and 10-18 years. Three (10.3\%) patients were in the 2-6-year-old group; 7 (24.1\%) in the 6-10-year-old group; $19(65.5 \%)$ in the 10-18-year-old group. The comparison of results in the age-related groups is summarized in Table 4. A comparison between the age-related groups showed significantly higher folate levels in the 2-6-year-old group $(\mathrm{p}=0.028)$ and higher ceruloplasmin level in the 6-10-yearold $(\mathrm{p}=0.018)$ compared to the other groups.

BMI of patients 10-18 years old was significantly higher $(p=0.001)$. No significant differences were observed in the distribution of height, weight and BMI percentiles between age-related groups ( $p>0.05, p>0.05$, and $p>0.05$, respectively), as well as the mean serum ferritin level between age-related groups ( $p>0.05$ ).

Patients were divided into three groups according to their serum ferritin levels and their data were compared. The mean selenium level was significantly higher in patients with a ferritin of $\geq 1,500(66.6 \pm 23.9 \mathrm{ug} / \mathrm{L})$ than in the group with $1,000-1,500(40.1 \pm 8.9 \mathrm{ug} / \mathrm{L})(\mathrm{p}=0.008)$. A weak positive significant positive relationship was found between serum ferritin and vitamin $C(p=0.035, r=0.392)$, whereas no significant ferritin-related differences in other nutrients ( $p>0.05$ ). A comparison of results in ferritin-related groups is summarized in Table 5 . A low BMD was determined in 4 patients, osteopenia in 2, and osteoporosis in 2. No significant difference was found between genders in terms of DXA results ( $p>0.05$ ).

Table 1. The prevalence of clinical and laboratory disorders in patients with thalassemia major.

Number of Frequency patients (n) $(\%)$

\begin{tabular}{|c|c|c|}
\hline \multicolumn{3}{|l|}{ Anthropometrics } \\
\hline Height of $<3 p$ & 7 & 24.1 \\
\hline Weight of $<3 p$ & 6 & 20.7 \\
\hline Weight of $>97 p$ & 0 & 0 \\
\hline BMI of $<5 p$ & 9 & 31.1 \\
\hline BMI of $>95 p$ & 0 & 0 \\
\hline $\begin{array}{l}\text { Micronutrient deficiency/ } \\
\text { insufficiency: Vitamin B12 }\end{array}$ & 3 & 10.3 \\
\hline Vitamin C & 3 & 10.3 \\
\hline Vitamin D & 21 & 72.4 \\
\hline Vitamin E & 1 & 3.5 \\
\hline Folate & 11 & 37.9 \\
\hline Copper & 1 & 3.5 \\
\hline Selenium & 21 & 72.4 \\
\hline Zinc & 2 & 6.9 \\
\hline \multicolumn{3}{|l|}{ Biochemical disorders } \\
\hline Hypocalcemia & 5 & 17.2 \\
\hline Hypophosphatemia & 0 & 0 \\
\hline Hypomagnesemia & 1 & 3.5 \\
\hline \multicolumn{3}{|l|}{ Increased ALP } \\
\hline Hypoalbuminemia & 0 & 0 \\
\hline Hypoproteinemia & 0 & 0 \\
\hline Decreased ceruloplasmin & 3 & 10.3 \\
\hline Increased HbAlc & 18 & 62.1 \\
\hline Hyperglycemia & 5 & 17.2 \\
\hline \multicolumn{3}{|l|}{ Endocrine disorders } \\
\hline Hypoparathyroidism & 4 & 13.8 \\
\hline Hypothyroidism & 1 & 3.5 \\
\hline Hyperinsulinemia & 1 & 3.5 \\
\hline \multicolumn{3}{|c|}{ Bone mineralization defects } \\
\hline Osteopenia & 2 & 7.4 \\
\hline Osteoporosis & 2 & 7.4 \\
\hline
\end{tabular}


BMD did not significantly differ in terms of mean serum ferritin concentration and mean serum micronutrient levels ( $p>0.05$ ). Characteristics, micronutrient levels, and comparison of patients according to DXA results are summarized in Table 6.

\section{DISCUSSION}

A significant prolongation was achieved with regular erythrocyte suspension transfusion and chelation therapy in patients with TM; however, complications due to iron accumulation in tissues still maintain their importance ${ }^{1.5,6}$. Bone mineralization disorders, growth failure, and endocrinopathies are common complications associated

\begin{tabular}{|c|c|c|c|}
\hline & & $\mathbf{n}$ & $\%$ \\
\hline \multirow{4}{*}{ Height } & $<3 p$ & 7 & 24.1 \\
\hline & $3-50 p$ & 11 & 37.9 \\
\hline & $\begin{array}{l}50-97 \\
\mathrm{p}\end{array}$ & 11 & 37.9 \\
\hline & $>97 p$ & 0 & 0 \\
\hline \multirow{4}{*}{ Weight } & $<3 p$ & 6 & 20.7 \\
\hline & $3-50 p$ & 19 & 65.5 \\
\hline & $\begin{array}{l}50-97 \\
\mathrm{p}\end{array}$ & 4 & 13.8 \\
\hline & $>97 \mathrm{p}$ & 0 & 0 \\
\hline \multirow{4}{*}{ BMI } & $<5 p$ & 9 & 31.01 \\
\hline & $5-50 p$ & 16 & 55.2 \\
\hline & $\begin{array}{l}50-95 \\
\mathrm{p}\end{array}$ & 4 & 13.8 \\
\hline & $>95 \mathrm{p}$ & 0 & 0 \\
\hline
\end{tabular}

with an iron overload ${ }^{5-7}$. Chronic hypoxia due to anemia, chelation therapy side effects, low zinc levels, and endocrinopathies are some of the leading factors for short stature and growth failure ${ }^{8.9}$. A significant proportion of short stature was observed, of which $24.1 \%$ of patients have $<3 \%$ height but without a significant relationship between height and ferritin or other micronutrient elements. A previous study revealed that $49 \%$ of patients had short stature and $43 \%$ had low BMI ${ }^{10}$. Similarly, Hashemi's study revealed a $65.7 \%$ short stature". Contrary to ours, some prior reports revealed no significant differences between patients with thalassemia and control groups in terms of growth $^{12}$. In terms of body weight, $20.7 \%$ of our patients were $<3 \mathrm{p}$. The BMI of $31 \%$ of patients was $<5 \mathrm{p}$, between 5 and 50 in $55.2 \%$ of patients, and between 50 and $95 p$ in $13.8 \%$ of patients, which are similar to previous studies. Hashemi et al.'s" study revealed that $45.1 \%$ of patients had low weight, whereas $18.6 \%$ had low BMI. Napoli et al. $^{10}$ reported a decreased BMI at a rate of $47 \%$. Hamed and El-Melegy ${ }^{12}$ and Vogiatzi et al. ${ }^{7}$ revealed that height and BMI in thalassemic children are not different from control groups, unlike our results. Cunningham et al.'s ${ }^{13}$ study revealed the endocrinological complication in $48 \%$ of patients with TM between the ages of 16 and 24 years and reached $52 \%$ after 25 years. Our study revealed no significant difference between age-related groups in terms of growth and endocrine disorders. Osteopenia and osteoporosis can develop despite regular treatment ${ }^{5,6,8}$. The most important way to prevent osteoporosis is the prevention of iron overload with effective chelation therapy. Contrarily, no significant relationship was determined between DXA and ferritin values, which we relate to the small number of our patients. The study conducted by Casale et al. $^{14}$ revealed a $44.9 \%$ rate of osteoporosis, which decreased to $26.5 \%$ at the end of the

Table 3. Ferritin levels according to anthropometrics.

\begin{tabular}{|c|c|c|c|c|}
\hline \multicolumn{5}{|c|}{ Ferritin (ng/mL) } \\
\hline & & Mean \pm SD & Range & p-values \\
\hline \multirow{3}{*}{ Height } & $<3 p$ & $1095.0 \pm 540.9$ & $475.0-2222.0$ & \multirow{3}{*}{0.479} \\
\hline & $3-50 p$ & $1022.7 \pm 449.2$ & $363.0-1728.0$ & \\
\hline & $50-97 p$ & $1335.0 \pm 658.4$ & $584.0-2842.0$ & \\
\hline \multirow{3}{*}{ Weight } & $<3 p$ & $984.2 \pm 339.6$ & $475.0-1510.0$ & \multirow{3}{*}{0.147} \\
\hline & $3-50 p$ & $1136.2 \pm 624.5$ & $363.0-2842.0$ & \\
\hline & $50-97 p$ & $1526.8 \pm 341.9$ & $1167.0-1988.0$ & \\
\hline \multirow{3}{*}{ BMI } & $<5 p$ & $1044.7 \pm 536.2$ & $554.0-2222.0$ & \multirow{3}{*}{0.553} \\
\hline & $5-50 p$ & $1204.8 \pm 567.6$ & $475.0-2842.0$ & \\
\hline & $50-95 p$ & $1230.5 \pm 677.4$ & $363.0-1988.0$ & \\
\hline
\end{tabular}




\begin{tabular}{|c|c|c|c|c|}
\hline & $\begin{array}{l}\text { 2-6 years } \\
\text { mean } \pm S D\end{array}$ & $\begin{array}{l}\text { 6-10 years } \\
\text { mean } \pm \text { SD }\end{array}$ & $\begin{array}{l}10-18 \text { years } \\
\text { mean } \pm \text { SD }\end{array}$ & p-value \\
\hline Ferritin & $671.43 \pm 320.29$ & $1037.28 \pm 676.92$ & $1173.39 \pm 550.77$ & 0.326 \\
\hline Vitamin B12 & $472.0 \pm 97.1$ & $324.4 \pm 133.4$ & $376.7 \pm 227.9$ & 0.287 \\
\hline Vitamin C & $23.8 \pm 25.3$ & $17.8 \pm 9.4$ & $10.66 \pm 6.8$ & 0.231 \\
\hline Vitamin E & $0.7 \pm 0.2$ & $0.5 \pm 0.1$ & $0.6 \pm 0.2$ & 0.440 \\
\hline Vitamin D & $20.0 \pm 3.6$ & $13.9 \pm 5.9$ & $13.3 \pm 7.1$ & 0.200 \\
\hline Folate & $17.0 \pm 0.9$ & $8.1 \pm 8.4$ & $3.5 \pm 2.5$ & 0.028 \\
\hline Zinc & $73.33 \pm 11.9$ & $77.3 \pm 10.4$ & $86.9 \pm 15.6$ & 0.140 \\
\hline Copper & $68.7 \pm 49.1$ & $90.7 \pm 17.7$ & $72.0 \pm 19.9$ & 0.091 \\
\hline Selenium & $55.2 \pm 19.1$ & $51.5 \pm 18.7$ & $54.4 \pm 20.5$ & 0.921 \\
\hline Ceruloplasmin & $29.3 \pm 3.2$ & $31.0 \pm 4.4$ & $24.6 \pm 8.8$ & 0.018 \\
\hline Albumin & $4.6 \pm 0.6$ & $4.4 \pm 0.2$ & $4.5 \pm 0.3$ & 0.284 \\
\hline Total protein & $6.8 \pm 0.9$ & $6.9 \pm 0.2$ & $7.2 \pm 0.6$ & 0.235 \\
\hline Calcium & $9.8 \pm 0.9$ & $9.3 \pm 0.5$ & $9.3 \pm 0.6$ & 0.492 \\
\hline Phosphorus & $5.7 \pm 1.1$ & $4.6 \pm 0.5$ & $4.3 \pm 0.7$ & 0.051 \\
\hline Magnesium & $2.1 \pm 0.3$ & $1.9 \pm 0.12$ & $1.9 \pm 0.2$ & 0.897 \\
\hline ALP (IU/L) & $170.0 \pm 43.9$ & $143.9 \pm 49.5$ & $170.6 \pm 104.1$ & 0.808 \\
\hline TSH & $2.9 \pm 1.8$ & $2.21 \pm 0.52$ & $2.1 \pm 0.7$ & 0.534 \\
\hline $\mathrm{T} 4$ & $1.0 \pm 0.1$ & $1.1 \pm 0.1$ & $1.0 \pm 0.1$ & 0.076 \\
\hline Glucose (mg/dL) & $88.42 \pm 5.72$ & $91.42 \pm 6.72$ & $89.8 \pm 6.48$ & 0.771 \\
\hline HbAlc & $6.12 \pm 1.7$ & $6.19 \pm 1.66$ & $6.23 \pm 1.28$ & 0.77 \\
\hline Insulin & $3.9 \pm 3.7$ & $7.5 \pm 5.9$ & $8.6 \pm 5.8$ & 0.173 \\
\hline PTH $(\mathrm{pg} / \mathrm{mL})$ & $28.6 \pm 4.0$ & $22.9 \pm 5.2$ & $30.2 \pm 11.5$ & 0.168 \\
\hline
\end{tabular}

3-year follow-up period by making chelation treatments more effective ${ }^{14}$. Our study revealed that $6.9 \%$ of patients have osteopenia and $6.9 \%$ have osteoporosis. Vitamin D deficiency frequency was $72.41 \%$ and was similar to prior studies, which have reported as $54 \%, 69.8 \%$, and $90 \% \%^{10.15 .16}$. Vitamin D deficiency is thought to be related to hepatic dysfunction and defective vitamin D hydroxylation due to iron overload ${ }^{17}$. No significant relationship or correlation was determined between vitamin $\mathrm{D}$ and ferritin. Yu et al.'s ${ }^{16}$ study revealed normal vitamin D levels in patients $<5$ years and that the deficiency progressively increased with age. Our study revealed no significant difference between the age groups. Bone metabolism defects have been demonstrated in many studies; however, their cause remains controversial ${ }^{15-17}$. The risk of developing endocrine disorders increases as ferritin increase ${ }^{16-19}$. The study conducted by Casale et al. ${ }^{14}$ revealed hypoparathyroidism in $2.3 \%$ of patients. Our study revealed hypoparathyroidism in $13.8 \%$ of patients, without a significant relationship or correlation between ferritin and PTH levels. Additionally, no age-related difference was found. The most commonly used method for nutritional status evaluation of patients is the serum levels of minerals and vitamins. Increased loss, increased needs for micronutrients, and calcium deficiencies are common in TM due to poor dietary intake. Particularly, minerals, such as zinc, calcium, and albumin, with some transport proteins are excreted in the urine ${ }^{2,8}$. The study conducted by Goldberg et al. ${ }^{2}$ revealed that $40 \%$ of patients who were adequately fed were found to have low zinc, $20 \%$ copper, and $20 \%$ vitamin C. The increased iron load in the body in TM leads to the rapid oxidation of vitamin $\mathrm{C}$, which ultimately leads to vitamin $\mathrm{C}$ deficiency in these patients. Our study revealed a weak positive correlation between vitamin $\mathrm{C}$ and ferritin levels in our patients $(\mathrm{p}=0.035)$.

Selenium deficiency was observed in $72.4 \%$ of patients and constitutes a very high rate. Calcium, magnesium, and other nutrient deficiencies were at lower rates and were similar to the literature ${ }^{20}$. No significant relationship 
Table 5. Comparison of the ferritin-related groups for the results.

\begin{tabular}{|l|l|l|l|l|}
\hline & $\begin{array}{l}\mathbf{1}, \mathbf{0 0 0} \mathbf{~ u g} / \mathbf{L} \\
\text { mean } \pm \text { SD }\end{array}$ & $\begin{array}{l}\mathbf{1 , 0 0 0}-1, \mathbf{5 0 0} \text { ug/L } \\
\text { mean } \pm \text { SD }\end{array}$ & $\begin{array}{l}\geq \mathbf{1 , 5 0 0} \text { ug/L } \\
\text { mean } \pm \text { SD }\end{array}$ & p-value \\
\hline Age (years) & $13.38 \pm 4.15$ & $11.25 \pm 4.01$ & $10.97 \pm 6.07$ & 0.290 \\
\hline Vitamin BI2 (pg/mL) & $388.67 \pm 221.97$ & $384.89 \pm 234.00$ & $339.50 \pm 127.07$ & 0.958 \\
\hline Vitamin C (mg/L) & $11.73 \pm 13.47$ & $13.81 \pm 7.85$ & $16.42 \pm 9.30$ & 0.137 \\
\hline Vitamin D (ng/mL) & $15.68 \pm 6.92$ & $11.89 \pm 5.51$ & $14.39 \pm 7.68$ & 0.463 \\
\hline Vitamin E (mg/dL) & $0.56 \pm 0.19$ & $0.56 \pm 0.20$ & $0.63 \pm 0.23$ & 0.716 \\
\hline Folat (ng/mL) & $4.48 \pm 4.03$ & $6.84 \pm 7.67$ & $7.44 \pm 7.01$ & 1.000 \\
\hline Zinc (ug/L) & $87.17 \pm 18.82$ & $81.33 \pm 13.71$ & $79.25 \pm 7.48$ & 0.657 \\
\hline Copper (ug/dL) & $76.25 \pm 25.15$ & $79.22 \pm 17.63$ & $72.63 \pm 29.82$ & 0.912 \\
\hline Selenium (ug/L) & $55.45 \pm 15.90$ & $40.13 \pm 8.99$ & $66.57 \pm 23.86$ & 0.008 \\
\hline Ceruloplasmin (mg/dL) & $27.43 \pm 9.59$ & $27.22 \pm 5.63$ & $24.75 \pm 8.14$ & 0.954 \\
\hline Albumin (g/L) & $4.39 \pm 0.30$ & $4.46 \pm 0.22$ & $4.60 \pm 0.36$ & 0.481 \\
\hline Total protein (g/L) & $7.08 \pm 0.51$ & $6.93 \pm 0.45$ & $7.29 \pm 0.74$ & 0.692 \\
\hline Ca (mg/dL) & $9.27 \pm 0.51$ & $9.30 \pm 0.68$ & $9.55 \pm 0.49$ & 0.475 \\
\hline P (mg/dL) & $4.33 \pm 0.82$ & $4.50 \pm 0.53$ & $4.82 \pm 1.03$ & 0.594 \\
\hline Mg (mg/dL) & $1.94 \pm 0.19$ & $1.99 \pm 0.18$ & $1.98 \pm 0.21$ & 0.851 \\
\hline ALP (Iu/L) & $188.33 \pm 116.78$ & $163.33 \pm 59.30$ & $128.63 \pm 56.20$ & 0.400 \\
\hline TSH (ulU/mL) & $2.26 \pm 0.74$ & $1.82 \pm 0.47$ & $2.65 \pm 1.06$ & 0.055 \\
\hline T4 (ng/mL) & $1.00 \pm 0.14$ & $1.05 \pm 0.12$ & $0.94 \pm 0.09$ & 0.147 \\
\hline PTH (pg/mL) & $31.91 \pm 10.47$ & $25.63 \pm 10.12$ & $25.66 \pm 8.70$ & 0.267 \\
\hline Glukoz (mg/dL) & $90.50 \pm 7.55$ & $87.67 \pm 6.04$ & $89.00 \pm 2.98$ & 0.744 \\
\hline Insulin (ulU/mL) & $8.54 \pm 6.43$ & $7.17 \pm 6.05$ & $7.45 \pm 4.56$ & 0.801 \\
\hline HbAlc & $5.82 \pm 1.30$ & $6.47 \pm 1.22$ & $6.25 \pm 1.32$ & 0.344 \\
\hline Kruskal-Wallis test, Ca: Calcium, P: Phosphorus, Mg: Magnesium, ALP: Alkaline phosphatase, TSH: Thyroid-stimulating hormone, PTH: Parathyroid hormone, \\
\hline SD: Standard deviation & & & & \\
\hline & & & & \\
\hline
\end{tabular}

\begin{tabular}{|c|c|c|c|c|}
\hline & $\begin{array}{l}\text { Normal } \\
n=22 \\
\text { F: } 9, \text { M: } 13\end{array}$ & $\begin{array}{l}\text { Osteopenia } \\
\text { n=2 } \\
\text { F: 1, M: } 1\end{array}$ & $\begin{array}{c}\text { Osteoporosis } \\
\text { n=2 } \\
\text { F: } \mathbf{0}, \mathrm{M}: \mathbf{2}\end{array}$ & p-value \\
\hline Ferritin $(\mathrm{ng} / \mathrm{mL})$ & $1149.92 \pm 587.62$ & $1233.00 \pm 391.74$ & $1193.00 \pm 475.18$ & 0.905 \\
\hline Age (year) & $12.74 \pm 4.24$ & $10.50 \pm 9.19$ & $7.96 \pm 7.95$ & 0.523 \\
\hline Vitamin B12 (pg/mL) & $373.68 \pm 208.12$ & $418.00 \pm 229.10$ & $333.00 \pm 83.44$ & 0.926 \\
\hline Vitamin C (mg/lt) & $14.41 \pm 11.28$ & $10.75 \pm 4.60$ & $7.30 \pm 3.25$ & 0.657 \\
\hline Vitamin D (ng/mL) & $14.29 \pm 6.63$ & $13.55 \pm 13.36$ & $12.95 \pm 4.31$ & 0.980 \\
\hline Vitamin E (mg/dL) & $0.57 \pm 0.21$ & $0.60 \pm 0.21$ & $0.61 \pm 0.13$ & 0.813 \\
\hline Folate $(\mathrm{ng} / \mathrm{mL})$ & $5.37 \pm 5.64$ & $10.05 \pm 11.24$ & $10.30 \pm 8.63$ & 0.471 \\
\hline Zinc (ug/L) & $81.40 \pm 13.96$ & $93.00 \pm 14.14$ & $95.50 \pm 26.16$ & 0.356 \\
\hline Copper (ug/dL) & $79.84 \pm 20.94$ & $31.00 \pm 25.46$ & $75.50 \pm 16.26$ & 0.067 \\
\hline Selenium(ug/L) & $53.29 \pm 20.23$ & $61.02 \pm 21.76$ & $52.35 \pm 3.75$ & 0.705 \\
\hline $\mathrm{Ca}(\mathrm{mg} / \mathrm{dL})$ & $9.26 \pm 0.50$ & $9.75 \pm 1.06$ & $10.10 \pm 0.00$ & 0.101 \\
\hline $\mathrm{P}(\mathrm{mg} / \mathrm{dL})$ & $4.37 \pm 0.68$ & $5.70 \pm 1.27$ & $5.25 \pm 1.06$ & 0.136 \\
\hline $\mathrm{Mg}(\mathrm{mg} / \mathrm{dL})$ & $1.96 \pm 0.18$ & $2.10 \pm 0.44$ & $1.93 \pm 0.08$ & 0.911 \\
\hline
\end{tabular}


or correlation was found between ferritin and nutrients in our results although increased iron accumulation plays an important role among the reasons for deficiencies, especially for vitamin C, E, and zinc levels in patients with an adequate nutritional history. Studies are yet to find the vitamin $\mathrm{E}$ needs in children with TM. Therefore, its routine use is not recommended. Patients with thalassemia do not have to follow a specific diet; however, they should have a balanced diet since nutritional deficiencies are closely associated with growth retardation and puberty delay ${ }^{21}$. Hypoproteinemia and hypoalbuminemia were not detected in any of our patients, and no significant correlation was found with ferritin levels but ceruloplasmin was under normal limits in $10.3 \%$ of patients. Food containing normal levels of fat and sugar is necessary to provide energy needs, especially for patients in the growing period; however, refined carbohydrates are not recommended to prevent the tendency of diabetes and glucose intolerance in adolescents ${ }^{2,8}$, which are particularly closely related to high iron accumulation in patients with thalassemia. Regular and effective chelation therapy can improve glucose tolerance, especially in the early period and control blood sugar and insulin release $\mathrm{e}^{8,22}$. Our study revealed that the high fasting blood glucose ratio was 3.5\% and the high insulin level ratio was also $3.5 \%$. HbAlc is known as an unreliable diabetic index in thalassemia due to hemolysis and transfusions, thus our high rate of HbAlc is explained. Folate need increases with increased erythropoiesis, especially in patients who are infrequently transfused. Folate deficiency was observed at a high rate and was thought to be associated with supplementation compliance. Abnormal thyroid functions are often reversible with effective chelation ${ }^{8,23,24}$. The rate of hypothyroidism in TM was $19.8 \%$ in the study conducted by Casale et al. ${ }^{14}$ and $10.8 \%$ in a multi-center study from Italy 25 . Our rate was smaller than these reports and without a significant relationship with ferritin.

\section{CONCLUSIONS}

Our study highlights the importance of nutritional deficiencies in children with thalassemia. Despite regular transfusion and effective chelation treatment, short stature, endocrinological disorders, osteoporosis, vitamin $\mathrm{D}$, and other nutritional deficiencies are common in these patients. Ensuring that they receive nutritional support when necessary is important. Preventing these complications and nutritional deficiencies and increasing the life expectancy and quality of patients is necessary. The small sample of our patients may affect this study, which needs to be further investigated in larger groups.
Acknowledgments: We gratefully acknowledge our patients and their families.

\section{Ethics}

Ethics Committee Approval: The study protocol was approved by the University of Health Sciences Turkey, Istanbul Medeniyet University Goztepe Training and Research Hospital Clinical Research Ethics Committee (decision no: 2019/0267, date: 22.05.2019).

Informed Consent: Written informed consent was obtained from the parents.

Peer-review: Externally and internally peer-reviewed.

\section{Author Contributions}

Concept: S.C.B., A.C.A., H.C.E., F.O., Design: S.C.B., A.C.A., H.C.E., F.O., Data Collection and/or Processing: S.C.B., A.C.A., H.C.E., F.O., Analysis and/or Interpretation: S.C.B., A.C.A., H.C.E., F.O., Critical Revision: S.C.B., A.C.A., H.C.E., F.O., Writing: S.C.B., A.C.A., H.C.E., F.O.

Conflict of Interest: The authors have no conflict of interest to declare.

Financial Disclosure: The authors declared that this study has received no financial support.

\section{REFERENCES}

1. Tubman VN, Fung BE, Vogiatzi M, et al. Guidelines for the standard monitoring of patients with thalassemia: report of the thalassemia longitudinal cohort. J Pediatr Hematol Oncol. 2015;37:e162-9.

2. Goldberg EK, Neogi S, Lal A, Higa A, Fung E. Nutritional deficiencies are common in patients with transfusion-dependent thalassemia and associated with iron overload. J Food Nutr Res (Newark). 2018;6:67481.

3. Neyzi O, Günoz H, Furman Andrzej, ve ark. Türk çocuklarında vücut ağırlığı, boy uzunluğu, baş çevresi ve vücut kitle indeksi referans değerleri. Çocuk Sağlığı ve Hastalıkları Dergisi. 2008;51:1-14.

4. Holick MF, Binkley NC, Bischoff-Ferrari HA, et al. Guidelines for preventing and treating vitamin D deficiency and insufficiency revisited. J Clin Endocrinol Metab. 2012;97:1153-8.

5. Cappellini MD, Porter JB, Viprakasit V, Taher A. A paradigm shift on beta-thalassemia treatment: how will we manage this old disease with new therapies? Blood Rev. 2018;32:300-11.

6. Taher AT, Cappellini MD. How I manage medical complications of $\beta$-thalassemia in adults. Blood. 2018;132:1781-91.

7. Vogiatzi MG, Macklin EA, Trachtenberg FL. Differences in the prevalence of growth. endocrine. and vitamin D abnormalities among the various thalassemia syndromes in North America. Br J Haematol. 2009;146:546-56.

8. Galanello R, Origa R. Beta-thalassemia. Orphanet J Rare Dis. 20101;5:11.

9. De-Sanctis V, Vullo C, Bagni B. Hyperparathyroidism in betathalassemia major: clinical and laboratory observations in 24 patients. Acta Hematol. 1992;88:105-8.

10. Napoli N, Carmina E, Bucchieri S, Sferrazza C, Rini GB, Di Fede G. Low serum levels of 25-hydroxy vitamin $D$ in adults affected by thalassemia major or intermedia. Bone. 2006;38:888-92. 
11. Hashemi A, Ghilian R, Golestan M, et al. The study of growth in thalassemic patients and its correlation with serum ferritin level. Ira J Ped Hem Oncol. 2011;1:147-51.

12. Hamed EA, El-Melegy NT. Renal functions in pediatric patients with beta-thalassemia major: relation to chelation therapy: an original prospective study. Ital J Pediatr. 2010;36:39.

13. Cunningham MJ, Macklin EA, Neufeld EJ. Complications of $\beta$-thalassemia majör in North America. Blood. 2004;104:34-9.

14. Casale M, Citarella S, Filosa A, et al. Endocrinfunctionand bone disease during long-term chelation therapy with deferasirox in patients with $\beta$-thalassemia major. Am J Hematol. 2014;89:1102-6.

15. Gaudio A, Morabito N, Xourafa A, et al. Bisphosphonates in the treatment of thalassemia- associated osteoporosis. J Endocrinol Invest. 2008;31:181-4.

16. Yu U, Chen L, Wang X, et al. Evaluation of the vitamin $\mathrm{D}$ and biomedical status of young children with $\beta$-thalassemia majör at a single center in southern China. BMC Pediatrics. 2019;19:375.

17. Fung EB, Aguilar C, Micaily I, Haines D, Lal A. Treatment of vitamin D deficiency in transfusion-dependent thalassemia. Am J Hematol. 2011;86:871-3.

18. De Sanctis V, Elsedfy H, Soliman AT, et al. Clinical and biochemical data of adult thalassemia majör patients with multiple endocrine complications versus TM patients with normal endocrine functions: a long-term retrospective study (40 years) in a tertiary care center in Italy. Mediterr J Hematol Infect Dis. 2016;8:e2016022. doi: 10.4084/ MJHID.2016.022.

19. Chirico V, Rigoli L, Lacquaniti A, et al. Endocrinopathies. metabolic disorders and iron overload in majör and intermedia thalassemia serum ferritin as a diagnostic and predictive marker associated with liver and cardiac T2* MRI assessment. Eur J Haematol. 2015;94:404-12.

20. Zamboni G, Marradi P, Tagliaro F. Parathroidhormone. calcitoninand vitamin D metabolites in beta thalassemia majör. Euro J Pediatr. 1986;145:133-6.

21. Fung EB, Xu Y, Trachtenberg F, et al. Inadequate dietary intake in patients with thalassemia. J Acad Nutr Diet. 2012;112:980-90.

22. Farmaki K, Angelopoulos N, Anagnostopoulos G, Gotsis E, Rombopoulos G, Tolis G. Effect of enhanced iron chelation therapy on glucose metabolism in patients with beta-thalassemia majör. $\mathrm{Br} \mathrm{J}$ Haematol. 2006;134:438-44.

23. De Sanctis V. Growth and puberty and its management in thalassemia. Horm Res. 2002;58:72-9.

24. Farmaki K, Tzoumari I, Pappa C, Chouliaras G, Berdoukas V. Normalisation of total body iron load with very intensive combined chelation reverses cardiac and endocrine complications of thalassemia major. Br J Haematol. 2010;148:466-75.

25. Borgna-Pignatti C, Rugolotto S, De Stefano P, et al. Survival and complications in patients with thalassemia major treated with transfusion and deferoxamine. Haematologica. 2004;89:1187-93. 